\title{
Capital Structure of Property Companies-Evidence from Bursa Malaysia
}

\author{
Abdul Razak Abdul Hadi ${ }^{1}$, Hamidi Yusoff ${ }^{1} \&$ Eddy Tat Hiung Yap $^{1}$ \\ ${ }^{1}$ Business School, Universiti Kuala Lumpur, Malaysia \\ Correspondence: Abdul Razak Abdul Hadi, Business School, Universiti Kuala Lumpur, Bangunan Yayasan \\ Selangor, Jalan Raja Muda Abdul Aziz, 50300 Kuala Lumpur, Malaysia. E-mail: abdrazak@unikl.edu.my
}

Received: April 7, 2015

Accepted: May 4, 2015

Online Published: July 25, 2015

doi:10.5539/ijef.v7n8p12

URL: http://dx.doi.org/10.5539/ijef.v7n8p12

\begin{abstract}
This study is to examine the relevance of company's capital structure in influencing its value. Within the framework of capital structure theories, this study uses Pearson Correlation methodology and Simple OLS Regression in measuring the strength of relationship between degree of leverage and share price. In using yearly time series data from January 2004 to December 2013, this study also measures the effect of earnings per share (EPS) on share price. It is found that EPS has more pervasive effect as compared to leverage in influencing firm's value. 45 out of 55 sample companies demonstrate positive relationship between EPS and share prices. However, only $31 \%$ shows significant relationship between EPS and share price. It is thus evident that the Modigliani-Miller theory provides better clarification compared to the Trade-Off theory in explaining Malaysian property firm's value.
\end{abstract}

Keywords: stock market, Bursa Malaysia, capital structure theories, Pearson correlation, OLS regression

\section{Introduction}

The capital structure of a firm is defined as the composition of a firm's capital with respect to the choice between equity and debt, and also of hybrid securities such as convertible debt and preferred shares. Equity financing is by the issuance of company shares and which are subscribed by shareholders. Debt financing is provided by banks or bondholders who receive loan contracts and publicly traded bonds in return for their money, respectively.

All rational firms seek optimal capital structure where cost of capital is minimized where the debt-equity mix maximizes the value of the company. There are some theories that could explain the optimal capital structure of firm. This paper attempts to find the best capital structure theory that provides satisfactory explanation of the financing behavior of 55 publicly-listed property firms in Malaysia over the period of January 2004 to December 2013. This paper uses panel data analysis, which is more comprehensive and unique from previous studies. Past papers mainly focus on developed countries, and these findings may not apply to the developing country of Malaysia.

It is generally known that many factors could affect the value of a firm. Specifically, this research attempts to find out as to whether size of debt-equity ratio or leverage could influence value of the firm proxied by stock price.

The objectives of this study are two-fold. Firstly, this research is to ascertain the effect of capital structure on the value of the firms i.e. is to establish the correlation and the significance of relationship between debt-equity (D/E) ratio and stock price of property companies in Malaysia. Secondly, the relationship between EPS and stock price is investigated and findings are reported in section four.

\section{Literature Review}

Modigliani and Miller introduced the Modigliani and Miller (MM) theory in 1958 which has two propositions. The first proposition argues that the firm's value and capital structure are independent where any capital structure selected would not affect the firm's value i.e. the value of a levered firm is the same as an unlevered firm. Under this theory, managers could freely choose any composition of debt and equity that makes up its capital structure. The second proposition posits that the cost of equity increases as leverage rises, due to increase in risk to equity rise as well. As such, the weighted average cost of capital remains constant as lower cost of debt is compensated 
with higher cost of equity. The cost of equity is constant with any degree of leverage and is a linear function of $\mathrm{D} / \mathrm{E}$ ratio.

The Trade-off theory by DeAngelo et al. (1980) posits that an optimal capital structure is based on the balance between the advantages and disadvantages of debt financing. An optimal capital structure thus is a point in the D/E ratio where the benefits of debt outweighs the cost of debt (Groth et al., 1997). Harris et al. (1991a and 1991b) noted that there are many studies arguing that tax issues, costs of financial distress, and agency problems between managers and shareholder and between managers and bondholders are some of the possible market imperfections on optimal capital structure. Aside from their research, some other influences also lead to an optimal trade-off e.g. industry effects affect debt ratios (Schwartz et al., 1967), higher R\&D expenditures indicating lesser leverage ratios (Long et al., 1985), and higher growth opportunities calling for lesser debt (Smith et al., 1992). Hovakimian et al. (2001) wrote that firms which have less debt than predicted, are also the firms most likely to issue debt.

Several papers support the observation that firms tend to adjust toward a target debt ratio, such as Graham (1996) and Flannery et al. (2006). Kester (1986), Titman et al. (1988), and Rajan et al. (1995) find strong negative relationships between debt ratios and past profitability. Wald (1999) observed that profitability is the single largest determinant of D/E ratio in a cross-sectional test of the United States, United Kingdom, Germany, France, and Japan.

Donaldson (1961) first proposed the Pecking Order theory, and Myers (1984) and Myers et al. (1984) further indicate that this theory is in reference to the preference of managers. According to Myers (1984), this theory explains that firms prefer internal finance (such as from retained earnings) to external finance. When outside funds are necessary, firms prefer debt rather than equity due to its lower cost. Equity, as the third preference after internal financing and debt, was found to rarely issued.

Myers et al. (1984) showed that asymmetric information (between managers who are better informed, and outside investors who are worse informed) leads firms' preference in the following order: firstly, internal funds, secondly, safer external funds, and thirdly, riskier external funds. For outside investors, equity is strictly riskier than debt and investors generally request a higher rate of return on equity than on debt. Retained earnings are superior to debt financing and equity financing, from the perspective of a firm.

In testing the Pecking Order theory, Shyam-Sunder etc (1999) introduced a new regression test which supported the Pecking Order theory, and suggested that firms plan to finance anticipated deficits with debt. They also reported that the result of the Pecking Order theory has more statistical power than the test of the Trade-off theory. Chirinko et al. (2000) questioned the interpretation of the regression test in Shyam-Sunder et al. (1999), demonstrating that equity issuances has a tendency to create a degree of negative bias in the Shyam-Sunder and Myers regression test.

Frank et al. (2003) reported that net equity issuances track the financing deficit closely, unlike net debt, which is antithesis from the perspective of the Pecking Order theory. In support of the Pecking Order theory, some researchers focus on the development of a satisfactory concept of debt capacity. Lemmon et al. (2004) found that the pecking order appears to be a good description of financing behavior for a large sample of firms, after controlling for debt capacity. A recent study by Serrasqueiro et al. (2015) found that the oldest and most profitable small and medium scale enterprises in Portugal tend to use less debt, supporting the Pecking Order theory. In a simple pecking order model, if the costs of financial distress are ignored, then the firm will finance real investment by issuing investment-grade debt, which is the safest security. However, a broader pecking order hypothesis accommodates some equity issues. If financial distress is serious, the firm would consider issuing equity to finance real investment or pare down debt.

The main difference between the Market Timing theory and the Pecking Order Theory is whether the assumption of semi-strong form market efficiency is maintained. In the Market Timing theory, windows of opportunity exist as long as the relative cost of equity changes over time. Baker et al. (2002) studied the direct linkage between the cost of equity and capital structre and founnd that an external finance-weighted average of historical market-to-book ratios is negatively related to current market leverage, interpreting this as evidence for market timing. Hovakimian (2004), Kayhan et al. (2004), and Aydogan (2006) then confirmed the existence of market timing in the issuance of securities.

On the basis of the previous research reviewed above, we find that few studies focus on less-developed stock markets (Delcoure, 2007), and to our knowledge only a few papers discuss the Pecking Order theory and the Market Timing theory at once. A recent research on Malaysia showed that public-listed companies tend to prefer issuing debts (Abdul Razak, 2014). In this paper, we utilise panel data analysis to test the Pecking Order theory 
and further examine the Market Timing theory by following the work of Baker et al. (2002).

\section{Methodology}

This study focuses on capital structure and stock price of property sector in Malaysia. A total of 56 companies listed on Bursa Malaysia were chosen (Appendix 1). 10-year data on total debt, total equity, average stock price, and earning per share (EPS) were obtained for each company. These financial data were retrieved from the Bloomberg database.

Formula below is used to calculate D/E ratio:

$$
\frac{D}{E} \text { Ratio }=\frac{\text { Total Debt }}{\text { Total Equity }}
$$

By using the above data, correlation test between D/E ratio and price and regression analysis were carried out using Microsoft Excel to determine the relationship between D/E ratio and stock price. In addition, correlation test between D/E ratio and EPS was also carried out.

Three main features are highlighted in our study. First, we examine each capital structure theory discussed in the study and find out to what extent it is relevant in explaining the choice between equity and debt financing in property sector. We then provide evidence on whether characteristics of an industry play an important role in explaining financing strategies. Second, we examine strength of relationship between value of the firm and its individual leverage. Finally, we perform the test of significance on their relationship and report their individual p-values.

\section{Empirical Results}

Table 1. Correlation between D/E ratio and price \& regression analysis (coefficient \& p-value)

\begin{tabular}{|c|c|c|c|c|}
\hline No. & Company & Corr (Price, DE) & Coefficient & P-value \\
\hline 1 & A\&M Realty Bhd & $-0.2080^{*}$ & -0.2062 & $0.0017 * *$ \\
\hline 2 & AmCorp Properties Bhd & 0.1277 & 0.0016 & 0.7252 \\
\hline 3 & Asas Dunia Bhd & $-0.5547 *$ & -0.0420 & 0.0961 \\
\hline 4 & Berjaya Assets Bhd & $-0.8517 *$ & -0.0147 & $0.0018^{* *}$ \\
\hline 5 & Country Heights Holdings Bhd & $-0.1223^{*}$ & -0.0007 & 0.7365 \\
\hline 6 & Country View Bhd & $-0.7823^{*}$ & -0.0208 & $0.0075^{* *}$ \\
\hline 7 & Crescendo Corp Bhd & $-0.1864 *$ & -0.0196 & 0.6061 \\
\hline 8 & Daiman Development Bhd & $-0.2870^{*}$ & -0.6311 & 0.4214 \\
\hline 9 & Damansara Realty Bhd & $-0.2038^{*}$ & -0.0024 & 0.5722 \\
\hline 10 & Eastern \& Oriental Bhd & 0.3271 & 0.0047 & 0.3562 \\
\hline 11 & Encorp Bhd & 0.0258 & 0.0001 & 0.9436 \\
\hline 12 & Eupe Corp Bhd & 0.3615 & 0.0357 & 0.3047 \\
\hline 13 & Glomac Bhd & $-0.4327^{*}$ & -0.0062 & 0.1213 \\
\hline 14 & GuocoLand Malaysia Bhd & $-0.4327 *$ & -0.0072 & 0.2116 \\
\hline 15 & Hua Yang Bhd & 0.6995 & 0.0325 & $0.0243 * *$ \\
\hline 16 & Hunza Properties Bhd & 0.2286 & 0.0044 & 0.5252 \\
\hline 17 & IGB Corp Bhd & 0.0899 & 0.0124 & 0.8049 \\
\hline 18 & IJM Land Bhd & 0.6404 & 0.0249 & $0.0461 * *$ \\
\hline 19 & Ibraco Bhd & 0.4386 & 0.0096 & 0.2048 \\
\hline 20 & Karambunai Corp Bhd & 0.1311 & 0.0003 & 0.7180 \\
\hline 21 & Keladi Maju Bhd & $-\wedge$ & $-\wedge$ & $-\wedge$ \\
\hline 22 & Ken Holdings Bhd & $-0.5963^{*}$ & -0.0326 & 0.0689 \\
\hline 23 & KSL Holdings Bhd & 0.4446 & 0.0257 & 0.1979 \\
\hline 24 & Kumpulan Hartanah Selangor Bhd & $-0.0726^{*}$ & -0.0020 & 0.8420 \\
\hline 25 & Land \& General Bhd & $-0.6727 *$ & -0.0006 & $0.0330 * *$ \\
\hline 26 & LBS Bina Group Bhd & $-0.2490^{*}$ & -0.0068 & 0.4879 \\
\hline 27 & Mah Sing Group Bhd & 0.0927 & -0.0022 & 0.7989 \\
\hline 28 & Malton Bhd & 0.2840 & -0.0067 & 0.4265 \\
\hline 29 & Magna Prima Bhd & 0.5483 & 0.0050 & 0.1008 \\
\hline 30 & Menang Corp Malaysia Bhd & 0.5742 & 0.0042 & 0.0826 \\
\hline
\end{tabular}




\begin{tabular}{|c|c|c|c|c|}
\hline 31 & MK Land Holdings Bhd & $-0.0062^{*}$ & -0.0002 & 0.9863 \\
\hline 32 & MKH Bhd & 0.7852 & 0.0216 & $0.0071 * *$ \\
\hline 33 & Nadayu Properties Bhd & 0.7356 & 0.0238 & $0.0153 * *$ \\
\hline 34 & Naim Holdings Bhd & $-0.4136^{*}$ & -0.0245 & 0.2348 \\
\hline 35 & OSK Property Holdings Bhd & 0.2424 & 0.0092 & 0.8276 \\
\hline 36 & Paramount Corp Bhd & 0.0793 & 0.0022 & 0.1922 \\
\hline 37 & PJ Development Holdings Bhd & 0.4497 & 0.0196 & $0.0333 * *$ \\
\hline 38 & Plenitude Bhd & $-0.6720 *$ & -0.1578 & 0.2460 \\
\hline 39 & SBC Corp Bhd & $-0.4047 *$ & -0.0107 & 0.1013 \\
\hline 40 & Selangor Dredging Bhd & 0.5476 & 0.0036 & 0.1013 \\
\hline 41 & Selangor Properties Bhd & $-0.6505^{*}$ & -0.0403 & $0.0417 * *$ \\
\hline 42 & SHL Consolidated Bhd & 0.0175 & 0.0007 & 0.9617 \\
\hline 43 & SP Setia Bhd & 0.2864 & 0.0098 & 0.4224 \\
\hline 44 & Sapura Resources Bhd & $-0.2588^{*}$ & -0.0024 & 0.4703 \\
\hline 45 & Symphony Life Bhd & 0.1374 & 0.0009 & 0.7050 \\
\hline 46 & Tanco Holdings Bhd & $-0.4285^{*}$ & -0.0002 & 0.2166 \\
\hline 47 & TAHPS Group Bhd & $-0.3045^{*}$ & -5.0823 & 0.3924 \\
\hline 48 & Talam Transform Bhd & $-0.2980^{*}$ & -0.0004 & 0.4029 \\
\hline 49 & Tiger Synergy Bhd & 0.4963 & 0.0025 & 0.1445 \\
\hline 50 & Tebrau Teguh Bhd & 0.4288 & 0.0511 & 0.2162 \\
\hline 51 & Tropicana Corp Bhd & 0.7294 & 0.0050 & $0.0167 * *$ \\
\hline 52 & Wing Tai Malaysia Bhd & 0.5935 & 0.0519 & 0.0705 \\
\hline 53 & Y\&G Corp Bhd & 0.8915 & 0.0084 & $0.0005 * *$ \\
\hline 54 & YNH Property Bhd & $-0.0171^{*}$ & -0.0007 & 0.9625 \\
\hline 55 & YTL Land \& Development Bhd & $-0.1074 *$ & -0.0008 & 0.7678 \\
\hline
\end{tabular}

Table 2. Types of correlation between $\mathrm{D} / \mathrm{E}$ ratio and price

\begin{tabular}{lll}
\hline Indicator & Description & No. of Companies \\
\hline$*$ & Negative correlation/coefficient value & 27 \\
& Positive correlation/coefficient value & 27 \\
& Incomplete data & 1 \\
& Total & 55 \\
$\wedge *$ & P-value $<0.05$ & 12 \\
$\wedge$ & P-value $>0.05$ & 42 \\
& Incomplete data & 1 \\
& Total & 55 \\
\hline
\end{tabular}

Table 3. Correlation between EPS and price \& regression analysis (coefficient $\&$ p-value)

\begin{tabular}{llccc}
\hline No. & Company & Corr (Price, EPS) & Coefficient & P-value \\
\hline 1 & A\&M Realty Bhd & 0.5616 & 4.7952 & 0.0912 \\
2 & AmCorp Properties Bhd & 0.2013 & 0.1985 & 0.5771 \\
3 & Asas Dunia Bhd & 0.8141 & 6.5048 & $0.0041^{* *}$ \\
4 & Berjaya Assets Bhd & 0.4194 & 1.3156 & 0.2276 \\
5 & Country Heights Holdings Bhd & 0.5972 & 1.3278 & 0.0683 \\
6 & Country View Bhd & 0.8617 & 2.0811 & $0.0014^{* *}$ \\
7 & Crescendo Corp Bhd & 0.6879 & 5.7466 & $0.0279^{* *}$ \\
8 & Daiman Development Bhd & 0.7194 & 4.6702 & $0.0190^{* *}$ \\
9 & Damansara Realty Bhd & $-0.7508^{*}$ & -5.2566 & $0.0123^{* *}$ \\
10 & Eastern \& Oriental Bhd & $-0.1460^{*}$ & -1.1804 & 0.6873 \\
11 & Encorp Bhd & 0.4728 & 0.7249 & 0.1676 \\
12 & Eupe Corp Bhd & 0.5846 & 2.1795 & 0.0759 \\
13 & Glomac Bhd & 0.5881 & 4.6560 & 0.0737 \\
14 & GuocoLand Malaysia Bhd & 0.2489 & 3.3655 & 0.4881 \\
\hline
\end{tabular}




\begin{tabular}{|c|c|c|c|c|}
\hline 15 & Hua Yang Bhd & 0.9692 & 6.1951 & $0.0000 * *$ \\
\hline 16 & Hunza Properties Bhd & 0.4516 & 0.7911 & 0.1902 \\
\hline 17 & IGB Corp Bhd & 0.8294 & 15.3346 & $0.0030 * *$ \\
\hline 18 & IJM Land Bhd & 0.3115 & 4.9891 & 0.3810 \\
\hline 19 & Ibraco Bhd & 0.8101 & 2.8682 & $0.0045^{* *}$ \\
\hline 20 & Karambunai Corp Bhd & $-0.3029 *$ & -0.2619 & 0.3949 \\
\hline 21 & Keladi Maju Bhd & 0.3878 & 0.9606 & 0.2681 \\
\hline 22 & Ken Holdings Bhd & 0.8384 & 3.4428 & $0.0024 * *$ \\
\hline 23 & KSL Holdings Bhd & 0.5079 & 2.7522 & 0.1339 \\
\hline 24 & Kumpulan Hartanah Selangor Bhd & 0.4175 & 0.7233 & 0.2299 \\
\hline 25 & Land \& General Bhd & 0.6217 & 0.7263 & 0.0550 \\
\hline 26 & LBS Bina Group Bhd & 0.7989 & 1.0816 & $0.0056^{* *}$ \\
\hline 27 & Mah Sing Group Bhd & 0.8633 & 8.2652 & $0.0013 * *$ \\
\hline 28 & Malton Bhd & 0.5770 & 1.5330 & 0.0808 \\
\hline 29 & Magna Prima Bhd & 0.3780 & 1.8822 & 0.2815 \\
\hline 30 & Menang Corp Malaysia Bhd & 0.0887 & 0.5179 & 0.8074 \\
\hline 31 & MK Land Holdings Bhd & 0.7990 & 7.0714 & $0.0056^{* *}$ \\
\hline 32 & MKH Bhd & 0.5513 & 5.2380 & 0.0985 \\
\hline 33 & Nadayu Properties Bhd & $-0.0754^{*}$ & -0.2662 & 0.8359 \\
\hline 34 & Naim Holdings Bhd & 0.2929 & .1 .3213 & 0.4115 \\
\hline 35 & OSK Property Holdings Bhd & 0.5093 & 2.5577 & 0.1327 \\
\hline 36 & Paramount Corp Bhd & 0.4859 & 1.9863 & 0.1545 \\
\hline 37 & PJ Development Holdings Bhd & 0.2040 & 0.9697 & 0.5718 \\
\hline 38 & Plenitude Bhd & 0.7276 & 8.9192 & $0.0171 * *$ \\
\hline 39 & SBC Corp Bhd & 0.8018 & 2.4126 & $0.0053 * *$ \\
\hline 40 & Selangor Dredging Bhd & $-00039^{*}$ & -0.0138 & 0.9914 \\
\hline 41 & Selangor Properties Bhd & $-0.0238^{*}$ & -0.2137 & 0.9480 \\
\hline 42 & SHL Consolidated Bhd & 0.0488 & 0.3253 & 0.8935 \\
\hline 43 & SP Setia Bhd & 0.6215 & 17.7846 & 0.0551 \\
\hline 44 & Sapura Resources Bhd & 0.1353 & 0.1494 & 0.7094 \\
\hline 45 & Symphony Life Bhd & 0.2630 & 0.1642 & 0.4629 \\
\hline 46 & Tanco Holdings Bhd & 0.8620 & 0.3525 & $0.0013 * *$ \\
\hline 47 & TAHPS Group Bhd & 0.0170 & 0.0912 & 0.9628 \\
\hline 48 & Talam Transform Bhd & 0.2440 & 0.1838 & 0.4970 \\
\hline 49 & Tiger Synergy Bhd & $-0.2577 *$ & -0.4181 & 0.4723 \\
\hline 50 & Tebrau Teguh Bhd & 0.7190 & 11.8693 & $0.0191 * *$ \\
\hline 51 & Tropicana Corp Bhd & 0.5774 & 1.4394 & 0.0805 \\
\hline 52 & Wing Tai Malaysia Bhd & 0.5074 & 2.0491 & 0.1344 \\
\hline 53 & Y\&G Corp Bhd & $-0.7352 *$ & -2.4545 & $0.0154 * *$ \\
\hline 54 & YNH Property Bhd & $-0.0145^{*}$ & -0.1482 & 0.9684 \\
\hline 55 & YTL Land \& Development Bhd & $-0.2650 *$ & -1.8420 & 0.4594 \\
\hline
\end{tabular}

Table 4. Types of correlation between EPS and price

\begin{tabular}{lll}
\hline Indicator & Description & No. of Companies \\
\hline$*$ & Negative correlation & 10 \\
& Positive correlation & 45 \\
& Total & 55 \\
\hline$* *$ & P-value $<0.05$ & 17 \\
& P-value $>0.05$ & 38 \\
& Total & 55 \\
\hline
\end{tabular}

\section{Discussion \& Conclusion}

Correlation test results show similar proportion of companies having positive and negative relationship of D/E ratio and stock price. There are 27 companies that have negative relationship between D/E ratio and price (the higher the debt proportion in the firm financing, the lower the stock price). Similarly, there are 27 companies 
showing positive correlation (the higher the debt proportion in the firm financing, the higher the stock price).

In terms of the magnitude of correlation, there are four companies that are highly positively correlated (i.e. when the value of correlation is between 0.7 and 0.9). Those are MKH Bhd, Nadayu Properties Bhd, Tropicana Corp Bhd, and Y\&G Corp Bhd. On the other hand, Berjaya Assets Bhd and Country View Bhd show a highly negatively correlation.

From the regression analysis, the sign and magnitude of coefficient (beta) corresponds to the correlation value as shown in Table 1. P-value of less than 0.05 is observed in only 11 companies. This means that at $95 \%$ confidence level, there is significant relationship between $\mathrm{D} / \mathrm{E}$ ratio and stock price involving these 11 companies. For firms having p-value of more than 0.05 , this implies an absence of significant relationship between their $\mathrm{D} / \mathrm{E}$ and stock price.

For the correlation between price and EPS, 45 out of 55 companies show positive correlation i.e. the higher the EPS, the higher the price. 13 from these 45 companies show high correlation. 17 companies or $30.9 \%$ shows significant relationship between price and EPS which is indicated by p-value of less than 0.05 .

In summary:

\begin{tabular}{lcc}
\hline Test Result & Number of companies & Percentage (\%) \\
\hline Correlation between Price and D/E Ratio & & $50.9 \%$ \\
Positive Corr (P, DE) & 27 & $49.1 \%$ \\
Negative Corr (P,DE) & 26 & $7.5 \%$ \\
High Positive Corr (P,DE) & 4 & $3.8 \%$ \\
High Negative Corr (P,DE) & 2 & $20.8 \%$ \\
P-Value (Regression of Price and D/E Ratio) & & $79.2 \%$ \\
$<0.05$ (significant relationship) & 11 & 42 \\
$>0.05$ (insignificant relationship) & & \\
\hline
\end{tabular}

\begin{tabular}{lcc}
\hline Test Result & Number of companies & Percentage (\%) \\
\hline Correlation between Price and EPS & & $81.8 \%$ \\
Positive Corr (EPS, DE) & 45 & $18.2 \%$ \\
Negative Corr (EPS, DE) & 10 & $23.6 \%$ \\
High Positive Corr (EPS, DE) & 13 & $3.6 \%$ \\
High Negative Corr (EPS, DE) & 2 & $30.9 \%$ \\
P-Value (Regression of Price and EPS) & 17 & $69.1 \%$ \\
$<0.05$ (significant relationship) & 38 & \\
$>0.05$ (insignificant relationship) & & \\
\hline
\end{tabular}

Our results show no support for the Pecking Order theory because debt financing matches every dollar of the shortage in financing deficits. It was discovered that EPS has more pervasive effect as compared to leverage ratio in influencing firm's value. 45 out of total 55 companies in the sample demonstrate positive relationships between EPS and share prices. However, only $31 \%$ of them support the presence of significant relationship between EPS and share price. All in all, the evidence presented in this study are very much in favour of Modigliani-Miller theory over the sample period.

\section{References}

Abdul Razak, N. H., \& Rosli, M. N. (2014). A Test between Pecking Order Hypothesis and Static Trade-Off Theory: An Analysis from Malaysian Listed Firms for Periods of Year 2007 To 2012. International Journal of Business \& Commerce, 3(5), 99-117.

Aydogan, A. (2006). How Persistent is the Impact of Market Timing on Capital Structure? Journal of Finance, 61, 1681-1710. http://dx.doi.org/10.1111/j.1540-6261.2006.00886.x

Baker, M., \& Wurgler, J. (2002). Marketing Timing and Capital Structure. Journal of Finance, 57, 1-32. http://dx.doi.org/10.1111/1540-6261.00414

Chirinko, R. S., \& Singha, A. R. (2000). Testing Static Tradeoff against Pecking Order Models of Capital 
Structure: A Critical Comment. Journal of Financial Economics, 58, 412-425. http://dx.doi.org/10.1016/S0304-405X(00)00078-7

DeAngelo, H., \& Masulis, R. W. (1980). Optimal Capital Structure Under Corporate and Personal Taxation. Journal of Financial Economics, 8(1), 3-27. http://dx.doi.org/10.1016/0304-405X(80)90019-7

Delcoure, N. (2007). The Determinants of Capital Structure in Transitional Economies. International Review of Economics and Finance, 16, 400-415. http://dx.doi.org/10.1016/j.iref.2005.03.005

Donaldson, G. (1961). Corporate Debt Capacity: A Study of Corporate Debt Policy and the Determination of Corporate Debt Capacity. Harvard Graduate School of Business Administration.

Flannery, M. J., \& Rangan, K. P. (2006). Partial Adjustment toward Target Capital Structure. Journal of Financial Economics, 79, 469-506. http://dx.doi.org/10.1016/j.jfineco.2005.03.004

Frank, M. Z., \& Goyal, V. K. (2003). Testing the Pecking Order Theory of Capital Structure. Journal of Financial Economics, 67, 217-248. http://dx.doi.org/10.1016/S0304-405X(02)00252-0

Graham, J. R. (1996). Debt and Marginal Tax Rate. Journal of Financial Economics, 41, 41-73. http://dx.doi.org/10.1016/0304-405X(95)00857-B

Groth, J.C. \& Anderson, R. C. (1997). Capital structure: perspectives for managers. Management Decision, 35(7), 552-561. http://dx.doi.org/10.1108/00251749710170529

Harris, M., \& Raviv, A. (1991). The Theory of Capital structure. Journal of Finance, 46, 297-355. http://dx.doi.org/10.1111/j.1540-6261.1991.tb03753.x

Hovakimian, A. (2004). Are Observed Capital Structures Determined by Equity Market Timing? Unpublished working paper, Baruch College.

Hovakimian, A., Opler, T., \& Titman, S. (2001). The Debt-Equity Choice. Journal of Financial and Quantitative Analysis, 36, 1-24. http://dx.doi.org/10.2307/2676195

Kayhan, A., \& Titman, S. (2004). Firms' Histories and their Capital Structure (Unpublished working paper). University of Texas at Austin. http://dx.doi.org/10.2139/ssrn.552144

Kester, C. W. (1986). Capital and Ownership Structure: A Comparison of United States and Japanese Manufacturing Corporation. Financial Management, 15, 5-16. http://dx.doi.org/10.2307/3665273

Lemmon, M. L., \& Zender, J. F. (2004). Debt Capacity and Tests of Capital Structure Theories. Working Paper. University of Utah.

Long, M., \& Malitz, I. (1985). The Investment-financing Nexus: Some Empirical Evidence. Midland Corporate Finance Journal, 3, 53-59.

Modigliani, F., \& Miller, M. H. (1958). The Cost of Capital, Corporation Finance, and the Theory of Investments. American Economic Review, 48, 261-297.

Myers, S. C. (1984). The Capital Structure Puzzle. Journal of Finance, 39, 575-592. http://dx.doi.org/10.2307/2327916

Myers, S. C., \& Majluf, N. (1984). Corporate Financing and Investment Decisions when Firms Have Information that Investors Do Not Have. Journal of Financial Economics, 13(2), 187-221. http://dx.doi.org/10.1016/0304-405X(84)90023-0

Rajan, R. G., \& Zingales, L. (1995). What Do We Know about Capital Structure? Some Evidence from $\begin{array}{lllll}\text { International Data. Journal of } & \text { Finance, } & 50, & 1421-1460 .\end{array}$ http://dx.doi.org/10.1111/j.1540-6261.1995.tb05184.x

Schwartz, E., \& Aronson, J. R. (1967). Some Surrogate Evidence in Support of the Concept of Optimal Financial Structure. Journal of Finance, 22, 10-18.

Serrasquiero, Z., \& Caetano, A. (2015). Trade-Off Theory versus Pecking Order Theory: Capital structure decisions in a peripheral region of Portugal. Journal of Business Economics and Management, 16(2), 445-466. http://dx.doi.org/10.3846/16111699.2012.744344

Shyam-Sunder, L., \& Myers, S. C. (1999). Testing Static Tradeoff against Pecking Order Models of Capital Structure. Journal of Financial Economics, 51, 219-244. http://dx.doi.org/10.1016/S0304-405X(98)00051-8

Smith, C. W., \& Watts, R. L. (1992). The Investment Opportunity Set and Corporate Financing, Dividend and Compensation Policies. Journal of Financial Economics, 21, 263-292. 
http://dx.doi.org/10.1016/0304-405X(92)90029-W

Titman, S., \& Wessels, R. (1988). The Determinants of Capital Structure Choice. Journal of Finance, 43, 1-21. http://dx.doi.org/10.1111/j.1540-6261.1988.tb02585.x

Wald, J. K. (1999). How Firm Characteristics Affect Capital Structure: An International Comparison. Journal of Financial Research, 22, 161-187. http://dx.doi.org/10.1111/j.1475-6803.1999.tb00721.x

\section{Copyrights}

Copyright for this article is retained by the author(s), with first publication rights granted to the journal.

This is an open-access article distributed under the terms and conditions of the Creative Commons Attribution license (http://creativecommons.org/licenses/by/3.0/). 